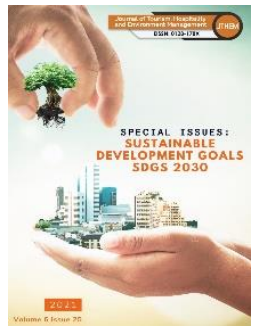

\author{
JOURNAL OF TOURISM, \\ HOSPITALITY AND \\ ENVIRONMENT MANAGEMENT \\ (JTHEM) \\ www.jthem.com
}

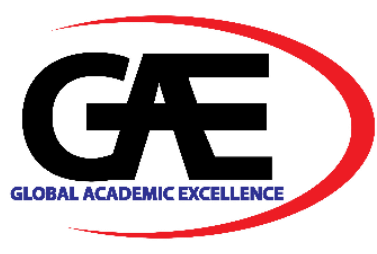

\title{
THE IMPACT OF COVID-19 PANDEMIC ON INCOME AND EMPLOYMENT IN THE AGRICULTURE AND FOOD SUPPLY INDUSTRY
}

\author{
Mohd Kamal Mohd Shah ${ }^{1 *}$ \\ 1 Faculty of Engineering, Universiti Malaysia Sabah, Malaysia \\ Email: mkamalms@ums.edu.my \\ * Corresponding Author
}

\section{Article Info:}

Article history:

Received date: 01.07 .2021

Revised date: 16.08 .2021

Accepted date: 30.09 .2021

Published date: 31.10 .2021

\section{To cite this document:}

Shah, M. K. M. (2021). The Impact Of Covid-19 Pandemic On Income And Employment In The Agriculture And Food Supply Industry. Journal of Tourism, Hospitality and Environment Management, 6 (25), 171-188.

DOI: $10.35631 /$ JTHEM.625013.

This work is licensed under $\mathrm{CC}$ BY 4.0

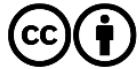

\begin{abstract}
:
This article discusses the impact of the Covid-19 pandemic on income and employment in the agricultural and food supply industries. Based on the background of the inaugural research method, this paper lays the research lens on a selection of contemporary issues including (i) the country's dependence on imported rice supply, (ii) the impact of Covid-19 on the Malaysian palm oil and rubber sector, (iii) private involvement in improving the economy of the agricultural sector, (iv) the rise of agricultural e-commerce and the food industry, and (v) the industrial revolution of the concept of Internet of Things (IoT). Reflections on the discussion focused on the impact of the Movement Control Order implementation on the agricultural community consisting of smallholders and rural communities who generate income by selling agricultural produce were unable to market their agricultural produce as well as facing the risk of job loss. However, Covid-19 also has a positive impact, namely the increase in online agricultural trade (E-commerce) under the control of the Electronic Commerce Act 2006 and the Consumer Protection Act 1999. The direction of research and development in the agricultural sector with the collaboration of the private sector is very important as a factor in developing the country's agricultural industry where the reduction of dependence on labour and instead increase the use of technology-intensive systems and environmentally friendly innovation.
\end{abstract}

Keywords:

Agricultural Industry And Food Supply, Covid-19 Pandemic, Agricultural E-Commerce 


\section{Introduction}

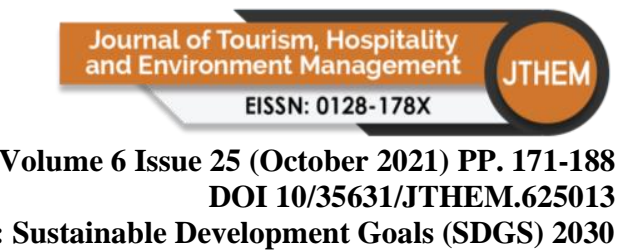

In this pandemic era, the three most affected economic industries in the country are construction, manufacturing and agriculture. The agricultural industry is one of the most important sources of economic income in Malaysia and has a major influence in economic development (Fabeil, Pazim \& Langgat, 2020). Among the sub-sectors in the agricultural industry are livestock, crops, aquaculture, forestry, logging and plantation. The industry is in decline due to the spread of the Covid-19 pandemic that has occurred around the world and is affecting the health of all parties (Abdul Aziz, Mohd Sukor \& Ab Razak, 2020). The pandemic causes infectious diseases that cause respiratory problems and can lead to death. To curb this pandemic, the government has implemented the Movement Control Order (MCO) under the Prevention and Control of Infectious Diseases Act (1988) (Berita Harian, 2020a).

This order has caused all activities of the agricultural sector such as the business of agricultural products, plantations and cultivation of agricultural resources to suffer a decline while curbing the spread of the pandemic from spreading to a more serious level. This also causes decline in the income of agricultural resources and affects the country's economic income. The decline in the agricultural industry has also affected the source of food supply in the country. This is because the production of most food supply products such as raw food consisting of vegetables, livestock meat and plantation products such as palm oil and rubber is reduced due to agricultural activities being disrupted due to the implementation of movement control order (Berita Harian, 2020a).

The spread of the Covid-19 pandemic has both positive and negative effects on the agricultural industry and food supply. Among the impacts are the increase in agricultural e-commerce, excessive amount of wastage on agricultural products, the decline of the aquaculture sector and affecting the income or employment of the agricultural community. However, Covid-19 also has a positive impact, namely the increase in online agricultural trade (E-commerce) under the control of the Electronic Commerce Act 2006 and the Consumer Protection Act 1999. The direction of research and development in the agricultural sector with the collaboration of the private sector is very important as a factor in developing the country's agricultural industry where the reduction of dependence on labour and instead increase the use of technology intensive systems and environmentally friendly innovation.

\section{Excessive Amount of Wastage on Agricultural Products}

The subsequent impact of Covid-19 on the agricultural industry and food supply is the excessive amounts of wastage on agricultural produces in the agricultural sector. For example, the problem of excessive amounts of vegetables wastage in Cameron Highlands (Hmetro, 2020a). This problem occurred due to several factors such as shortage of workers, closure of markets and business areas, the problem of roadblocks and lack of demand from public market operators. The shortage of workers occurred because most of the workers in vegetables stalls and lorry drivers for vegetable sales are foreign workers and during the $\mathrm{MCO}$, the number of foreign workers who could work has been limited. This situation makes if difficult for the activity of unloading vegetables into the market because the manpower required is insufficient and makes it difficult for business activities to be carried out (Sinar Harian, 2020).

In addition, the closure of most markets has forced vegetable supplies to be discarded as they cannot be sold (Hmetro, 2020a). This causes excessive vegetable yield that had to be discarded because vegetables are agricultural crops that cannot last long. Strict roadblocks made it even Copyright (C) GLOBAL ACADEMIC EXCELLENCE (M) SDN BHD - All rights reserved 


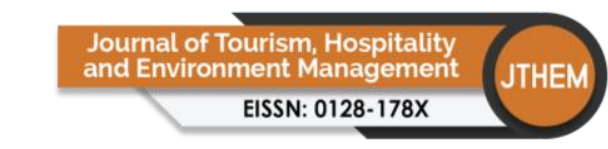

Volume 6 Issue 25 (October 2021) PP. 171-188

DOI 10/35631/JTHEM.625013

Special Issue: Sustainable Development Goals (SDGS) 2030

difficult for lorry drivers to deliver vegetable produce to the market for sale (Hmetro, 2020a). The procedures require lorry drivers to get past roadblocks which take time and some lorry drivers were not allowed to enter the market to deliver agricultural produce. As a result, agricultural produce could not be sent to the market for sale and caused it to be returned to the cultivation area and causing heaps of agricultural produce wastage. The decline in demand for vegetable supplies for sale by public market operators also contributed to the problem of excessive wastage of agricultural produce.

The implementation of the Movement Control Order resulted in some public markets not being allowed to operate and being ordered to close (Berita Harian, 2020a). This situation causes the supply of vegetables that are usually sent to the public market for sale to consumers is not supplied to vegetable operators as usual thus causing agricultural products to be produced in excessive amount without being used or traded to consumers (Sinar Harian, 2020). Meanwhile, for smallholders in Perak, the problem of excessive wastage of agricultural produce occurs due to marketing problems and methods of selling vegetables at retail (Utusan, 2021a).

Due to the Covid-19 outbreak, the marketing of vegetables is declining as wholesalers of vegetable produce reduce the rate or volume of their purchases due to the difficulty of selling such vegetable produce to consumers. Thus, the harvested vegetables had to be sold at retail. Retail sales depend on the number of customers while during MCO the number of customers were not many causing agricultural products were not sold out (Utusan, 2021a). In conclusion, due to the spread of Covid-19 pandemic which has caused the government to act by doing Movement Control Order and this has caused the excessive wastage of agricultural produce to occur.

\section{Deterioration of the Aquaculture Sector}

Aquaculture is the activity of breeding marine life such as fish, shrimp, shellfish and oysters in a controlled aquatic environment (Koris, Nik Mustapha, Abd. Aziz \& Muhamad, 2012). Astroawani, (2020a) stated that the aquaculture sector experienced a decline when there was an outbreak of Covid-19 in our country. Aquaculture operators are experiencing difficulty in conducting business activities due to the implementation of movement control order as a way to curb the outbreak. Due to the implementation of MCO, the demand for aquaculture livestock has decreased as most wholesalers and traders do not operate business. Currently, only a number of seafood markets and businesses are allowed to operate and conduct business activities. The reduction in seafood restaurants as well as public markets operating due to being ordered to close in curbing the spread of the Covid-19 pandemic has also reduced the demand for aquaculture livestock products (Astroawani, 2020a).

This situation caused a downturn in the aquaculture sector due to lack of demand from wholesalers or traders who normally provide seafood supplies in their businesses. Furthermore, there are restaurants or food outlets that provide seafood have stopped operating due to the movement control order. This has resulted in reduced demand for large-scale livestock products in the market. Other than that, the cost of care and management of aquaculture livestock also increased due to lack of demand from traders (Koris, Nik Mustapha, Abd. Aziz \& Muhamad, 2012). Livestock products that cannot be sold and marketed have to be cared for, for a longer period of time. As a result, aquaculture operators need more care and management costs to breed these fish and marine life. For example, fish feed cost, water supply 


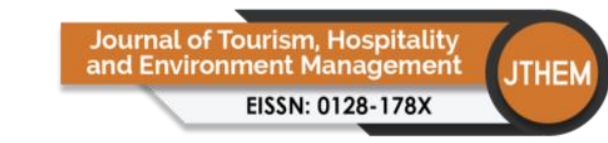

Volume 6 Issue 25 (October 2021) PP. 171-188

DOI 10/35631/JTHEM.625013

Special Issue: Sustainable Development Goals (SDGS) 2030

cost, pond cleaning cost and employee salaries. This causes aquaculture operators to experience financial constraint and can lead to bankruptcy.

Competition between the fisheries and aquaculture sectors during this pandemic was also one of the factors in the decline of the aquaculture sector (Astroawani, 2020a). Most customers or seafood traders prefer to buy fish and seafood from fishermen and at the market. This is because there is a decline in fish prices causing buying fish and seafood sold in the market in bulk is cheaper than buying with aquaculture operators. The lack of workers to operate fish pond and marine resources makes it difficult for aquaculture operators to carry out livestock care and management activities (Koris, Nik Mustapha, Abd. Aziz \& Muhamad, 2012). In addition, roadblocks imposed during the movement control order make it difficult and restrictive for operators to market their livestock products to other areas or districts. This has led to a decline in aquaculture livestock business activities. From the above description, it is clear that Covid-19 had a negative impact on the aquaculture sector as it caused a deterioration to this sector during a pandemic.

\section{Methodology}

The research methodology in this writing uses a qualitative approach referring to a research approach that requires careful observation with a focus on process and event management. Thematic and independent analysis of research findings based on information from various sources such as primary and secondary sources that utilise secondary data content analysis methods, namely the results of research journals, reports, books and online news sources. This approach is a popular design in the social sciences when it is often associated with ethnography, and sociology, law and historiography. The implementation of the law with the observation of discussion embroidered with the relevance of relevant acts such as the Electronic Commerce Act 2006 and the Consumer Protection Act 1999 also contributed positively to the legal control over the increase of online agricultural trade (E-commerce).

The social science discipline is used because to look at developments related to the impact of the Covid-19 pandemic on income and employment in the agricultural and food supply industries. Thus, there are several important events that touch on issues and challenges in the implementation of movement control order among the agricultural community who consist of smallholders and rural communities who generate income by selling agricultural products, but they cannot market their agricultural products and agricultural sector workers also face the risk of job loss. Apart from that, when discussing the research methodology of social science disciplines, it is then qualitative in nature mixed with descriptive analytical discussion (Sugiyono, 2009).

In this writing, a literature review is used by collecting primary and secondary sources to enable facts to be explained based on issues associated with actual events. The findings of the study also bring the relevance of development in the agricultural sector with the collaboration of the private sector. This is important as a factor in developing the county's agricultural industry where the reduction of dependence on labour and the increase use of technology-intensive systems and environmentally friendly innovation. 


\section{Literature Review}

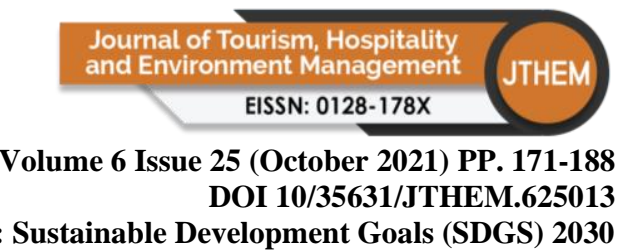

This paper lays the research lens on a selection of contemporary issues including (i) the country's dependence on imported rice supply, (ii) the impact of Covid-19 on the Malaysian palm oil and rubber sector, (iii) private involvement in improving the economy of the agricultural sector, (iv) the rise of agricultural e-commerce and the food industry, and (v) the industrial revolution of the concept of Internet of Things (IoT).

\section{National Dependence on Imported Rice Supply}

Food shortages are often an issue due to the occurrence of food crisis. Not only that, it has even become a serious issue faced by most countries around the world, including Malaysia. Therefore, agriculture has become a major resource to enable Malaysians in continuing the work to expand their food production capacity. The rice industry is one of the commodities given priority in Malaysia's food security (Tahir \& Abd Talip, 2020). In the current era, rice has become an important food commodity in Malaysia because the country has made many changes in producing food, especially producing a variety of high-quality rice. To show concern for this industry, the government has implemented the Policy starting with the First National Agricultural Policy (DPN1) in 1984, DPN2 in 1992, DPN3 in 1998 and the National Food Security Policy (DJBM) in 2008 and 2011 up until now (Chew \& Chamhuri, 2018).

These policies are very important because they are Food Security policies that also incorporate new philosophies and development directions as contained in the Second Outline Perspective Plan and Vision 2020 (Ministry of Agriculture Malaysia and Agro-based Industry, 1993). In addition, this policy is Malaysia's plan in the national development strategy which includes the National Agricultural Policy (NAP) and is formulated every 5 years to materialise and implement the programmes outlined in the NAP (Ministry of Agriculture Malaysia and Agrobased Industry, 1993). Rice is the country's main food commodity which is given special focus to increase Malaysia's main production. Various efforts have been made by the government to increase the production of this commodity to ensure the production of this food is secure.

The production of rice is the main production and the main thing in the NAP because the production is the staple food of the community in Malaysia (Tahir \& Abd Talip, 2020). It is proven that the need for that particular food influences the determination of the percentage of rice production in the country and the production takes the highest cost of food production. Due to this, Malaysia took the initiative to focus on rice cultivation in the main rice granary areas namely Muda Agricultural Development Authority (MADA), Kemubu, Besut, Northwest Selangor, Krian-Sungai Manik, Seberang Perak, Kemasin-Semerak and Seberang Perai (Zakaria, Mohd Nor, Mohamed Said, Ahmad \& Hassan, 2017). Meanwhile, rice production outside rice granary area will be gradually reduced and replaced with crops that bring more yield to the country (Zakaria, Mohd Nor, Mohamed Said, Ahmad \& Hassan, 2017).

Not only that, to ensure adequate supply of rice including for the storage stock at the level of 292,000 metric tonnes, Malaysia has increased productivity in the rice granary areas as well as outside the existing rice granaries through infrastructure upgrades during the 10MP (Economic Planning Unit, 2010). The proof is, new areas of rice cultivation will not be developed, and local rice production is set at $70 \%$ of the subsistence level (Economic Planning Unit, 2010). In addition, the government also provides new lands and improved drainage facilities and water lines in rice growing areas to facilitate increased rice production. Next, upgrading existing 


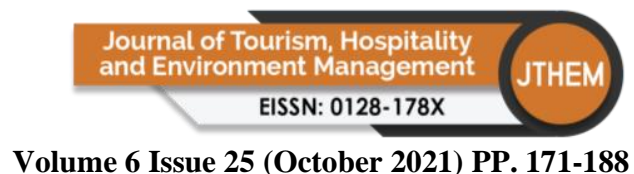

Volume 6 Issue 25 (October 2021) PP. 171-188

DOI 10/35631/JTHEM.625013

Special Issue: Sustainable Development Goals (SDGS) 2030

management practices for twice-yearly planting, use of high-yielding seeds are also strategies for increasing rice production. (Economic Planning Unit, 1996).

Based on the Minister of Agriculture and Food Industry explained that local rice production needs to be increased to ensure the country's rice supply is adequate for the needs of the people in our country. The government is reviewing the policy adopted to import rice from foreign countries for the country's use, including efforts to increase local rice production to 75 percent of total consumption over the next few years (Astroawani, 2020b). This is said to be so because the measure can reduce the country's dependence on imported rice, plus the current situation of the outbreak of Covid-19 that hit the world today. This is to meet the level of self-sufficiency or the needs of the people in Malaysia. In general, the level of production of rice crops in this country is still below the low level causing our country to still depend on imported rice to meet the needs of the people in this country. This is due to limited farm preparation, unsystematic adherence to planting schedules and loss of yield after harvest.

However, Malaysia is still considered a net importer even though our rice production is lower than the market demand because our country is still able to import most of the international market demand (Aris, Rameli, Mohamed, Abas \& Man, 2018). At the same time, the international rice trade scenario shows that Malaysia has great potential to participate as an exporter of this commodity (Hmetro, 2018). In addition, the instability of supply, increasing demand and the small quantity of rice trade in the international market make rice prices tend to be less competitive causing many people in the country to be less interested in cultivating local rice. This is because they think the industry does not provide big profits to entrepreneurs (Chew \& Chamhuri, 2018). Therefore, the implementation of the improvement of the agricultural system in our country must be implemented holistically to help maintain the sustainability of the country's rice industry, thus preserving the welfare of farmers in our country.

Among the strategies and efforts that can develop the rice industry is to increase the productivity and quality of rice, increase the effectiveness of mechanisation and automation, intensify the use of rice by-products, strengthen rice buffer stock management, structure incentives and subsidies for rice and strengthen management of rice institutions (Tahir \& Abd Talip, 2020). In this regard, rice production in the granary and outside granary will be enhanced through the provision of adequate irrigation and drainage infrastructure facilities, the use of high quality and high yielding rice seeds, the practice of accurate agricultural technology and more efficient agronomic management.

Thus, efforts to increase productivity in rice production areas are by using new varieties including hybrid varieties and legal rice seeds, expanding rice land consolidation and estate management, expanding the use of accurate agricultural technology and good practices in granaries and outside granaries with irrigation systems and enhance service delivery by Area Farmers Organisations (PPK) especially in terms of mechanisation and automation as well as encourage the ownership of small machinery among farmers (Aris, Rameli, Mohamed, Abas \& Man, 2018).

\section{Palm Oil and Rubber Sector Management}

The palm oil and rubber sectors are agricultural resources that have contributed a lot to the development of Malaysia both economically and socially. In the 1960s and 1970s the Copyright $\odot$ GLOBAL ACADEMIC EXCELLENCE (M) SDN BHD - All rights reserved 


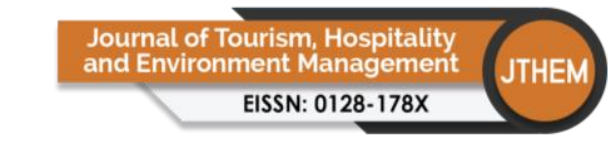

Volume 6 Issue 25 (October 2021) PP. 171-188

DOI 10/35631/JTHEM.625013

Special Issue: Sustainable Development Goals (SDGS) 2030

Malaysian economy depended on rubber and tin, but this began to change when palm oil yields were seriously developed through government efforts in the beginning of 1970s and 1980s (Abazue, Er, Ferdous Alam \& Halima, 2015). Currently, palm oil is the country's main commodity and Malaysia is the second largest producer of the commodity after Indonesia (Aziz, Alfitri, Sepeai, Nawi \& Er, 2021). As for rubber, the country is ranked seventh as the world's leading producer of rubber (Sinar Harian, 2021). In 2016, the total land area used for palm oil cultivation was 5.73 million hectares while for rubber cultivation it was 1.07 million hectares (Ministry of Plantation Industries and Commodities, 2018).

Both sectors are operated by the Ministry of Plantation Industries and Commodities. This department plays an important role in developing the country's commodity sector either in terms of management or production. Although the Covid-19 outbreak has impacted these sectors, the government has put in place appropriate measures to ensure the survival and development of the sector. GDP is an abbreviation for the term Gross Domestic Products. It is one of the factors used around the world to determine the level of economic development in a country. The palm oil and rubber sectors have proven to have a lot of importance in boosting the national economy. This can be seen when Malaysia was hit by the economic crisis, and production through the palm oil and rubber sectors has stabilised the country's economic situation at that time (Begum, Siwar, Ferdous, Er, Suraiya \& Lubna, 2018). For example, during the financial hit in the year 1998, the palm oil industry was able to contribute RM22.5 billion which had reduced the country's economic burden at that time (Berita Harian, 2020c).

Apart from that, when the Covid-19 outbreak hit Malaysia, although initially the palm oil and rubber industries were affected but the situation could be overcome after the disease prevention measures were implemented. Through online media and news on television we can see that the industry is starting to increase the level of the country's GDP, in fact it is getting more exhilarating. This may be due to the demand for medical gloves which is getting a surge in demand at home and abroad. Furthermore, the contribution of the palm oil and rubber industries is not only significant during the economic crisis. The earnings of this industry can be seen consistently over time. For example, from January to March 2021 this industry has managed to become the highest and second highest contributor to Malaysia's GDP in that time gap. Through rubber export production, the country's GDP managed to collect 21.8 billion while palm oil export revenue contributed 19.2 billion. As for import revenue, 7.7 billion is from rubber and 4.4 billion from palm oil (Ministry of Plantation Industries and Commodities, 2021).

\section{The Impact of Covid-19 on the Malaysian Palm Oil and Rubber Sector}

There were several negative impacts on the Covid-19 outbreak that could be clearly seen when the outbreak hit Malaysia. Among them, the impact of labour shortages. This affects important sectors of the country's commodities such as palm oil and rubber due to the lack of workers to carry out the production process. The palm oil sector which had previously monopolised by foreign workers is now facing challenges as large number of the foreigners were sent back to their respective countries and the borders between the countries were temporarily closed. This is one of the steps to break the Covid-19 pandemic chain. The implications have caused the labour force in palm oil sector to drop by up to $30 \%$ from normal and this impact will be worse than the impact of the decline in global palm oil prices (Berita Harian, 2021a). This is because if such a situation occurs then the production of palm oil will be reduced to half the normal level. This should be avoided because the palm oil commodity is the main commodity of the Copyright (C) GLOBAL ACADEMIC EXCELLENCE (M) SDN BHD - All rights reserved 


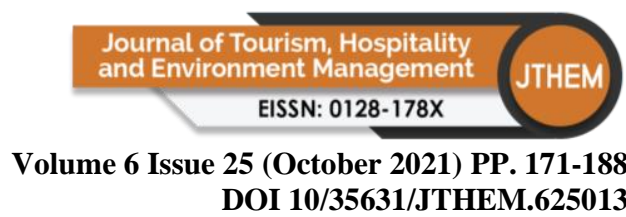

Special Issue: Sustainable Development Goals (SDGS) 2030 country and the lack of more than $80 \%$ of palm oil yield can affect the trade activities of the industry (Berita Harian, 2021a).

Apart from the affected processing of palm oil products, the manufacturing process of rubber gloves was also affected. Workers in rubber glove factories are also declining even though the industry is in dire need of workers due to increasing demand at home and abroad. As the world's largest producer of rubber gloves, Malaysia's trade activities were affected so much so that in 2019 the total production of rubber gloves had to be reduced from 195 billion units to 188 billion units only (Berita Harian, 2019a). This is clearly able to reduce the country's income because this year the country's GDP income from the rubber sector is the largest contributor to the country's GDP at the beginning of the year. If remedial measures are not taken, it will cause a severe impact because entrepreneurs are unable to meet the growing domestic and foreign demand (Berita Harian, 2019a). Besides labour shortages, volatile global palm oil and rubber prices have also affected the country's major commodities. With the volatile setting of palm oil prices, this has affected the income of Malaysians.

This is because if the price of palm oil products is not fixed, entrepreneurs must take into account the risk of losses that can occur due to various aspects. For example, aspects of demand and production, market networking, financial risks, supply chain disruptions and the introduction of new oil sources such as soybeans. Therefore, palm oil operators are advised to take precautions to ensure that losses can be controlled and overcome (Sinar Harian, 2021). Meanwhile, in the rubber industry the decline in rubber prices affected the income of rubber tappers. This is also related to weather factors that do not allow them to tap and high rubber taxes. For example, rubber tappers in Padang Terap Kedah (Sinar Harian, 2019). The drop in the price of rubber to reach RM2.19 per kilogram worries the residents. Most of the villagers depend on rubber for their livelihood. When the price of rubber dropped and the rainy season did not allow them to do rubber tapping in just ten days, this burdened the residents as they did not have enough income to buy food sources.

Apart from that, the high rubber tax also increases their burden because with their low income plus a tax of RM70 for a rubber sheet further reduces their income (Sinar Harian, 2019). Management of the Palm oil and Rubber Sector during Covid-19 saw that although the Covid19 outbreak had affected the country's revenue through the palm oil and rubber sector during the early stages of its spread in Malaysia, the government had set a Standard Operation Procedure (SOP) to assist workers in the sector to ensure they are safe to work and able to meet customer demand (Abdul Aziz, Mohd Sukor \& Ab Razak, 2020). This can be achieved because the SOP is able to protect workers and employers from being infected with this pandemic and at the same time ensuring they work efficiently, productively and without any problems. The SOPs set by the government to provide flexibility to the country's two main commodities include 3 actions namely providing a set of rules to reduce the risk of infectious diseases, conducting daily health screenings and employers must report the health of each employee hired (National Defence Department, 2020).

In conclusion, the country's palm oil and rubber have proven to contribute a lot and are the most important commodity sectors in leading the country's economic development. The Ministry of Industries and Commodities which operates this sector, plays an important role in developing this commodity sector as well as ensuring that the challenges faced can be overcome. The palm oil and rubber industry which is the highest and second highest contributor Copyright (C) GLOBAL ACADEMIC EXCELLENCE (M) SDN BHD - All rights reserved 


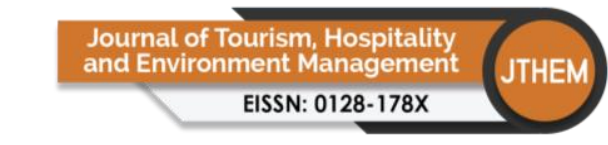

Volume 6 Issue 25 (October 2021) PP. 171-188

DOI 10/35631/JTHEM.625013

Special Issue: Sustainable Development Goals (SDGS) 2030

to the country's GDP is able to stabilise the country's income when Malaysia is experiencing an economic crisis due to various factors. Factors such as disease outbreaks resulting in labour shortages and floor price instability of oil and natural rubber products globally have affected the country's economy in the early stages of its contagion. Yet, the results of the government's efforts through the enforcement of the Standard Operation Procedure (SOP) have been effective as a strategy to break the Covid-19 chain and to some extent helped palm oil and rubber operators to recover their incomes (Abdul Aziz, Mohd Sukor \& Ab Razak, 2020).

\section{Private Involvement in Improving the Economy of the Agricultural Sector}

The 2021 Budget which was presented by the Minister of Finance Tengku Datuk Seri Zafrul Tengku Abdul Aziz on $6^{\text {th }}$ November last year is a financial planning strategy that provides large allocations to ensure the survival of the people and the strengthening of the country's economy despite the current situation of the Covid-19 pandemic in the country that is still in a situation that worries all Malaysian (Berita Harian, 2020d). The 2021 budget focuses on helping the people facing current challenges, especially those who were affected such as B40 households as well as frontline workers, health workers, etc., even though the government has to face constraints due to the effects of the Covid-19 pandemic (Berita Harian, 2020d). The presentation of the 2021 Budget also includes implementing more efforts to encourage the private sector to drive the country's economic growth. In this case, the agricultural sector is no exception in helping to improve the country's economy. This is because this sector is able to contribute to the country's source of income through high export growth, especially products produced from commodities such as palm oil, rubber and cocoa (Fabeil, Pazim \& Langgat, 2020).

The government has reviewed relevant proposals in providing more effective and attractive incentives to encourage the private sector to increase investment in labour-saving technologies in order to increase productivity and agricultural production at the same time. This is said to be so because the country's agricultural sector should reduce its dependence on labour and instead increase its use in technology-intensive systems and environmentally friendly innovations (Zakaria, Mohd Nor, Mohamed Said, Ahmad \& Hassan, 2017). In this regard, our country not only reduce the need for labour service, but also reduce dependence on foreign labour which is increasingly worrying the future of the country. This is because the matter can give a negative impact especially to the community in the country itself which causes a lack of employment opportunities for locals (Zakaria, Mohd Nor, Mohamed Said, Ahmad \& Hassan, 2017).

In this regard, Malaysia will also face new challenges in maintaining peace and harmony of the people as well as threatening national security with the entry of foreign labour into the country's employment sector. Academics have stated that the number two enemy of the country now is foreigners who come to Malaysia (Hamzah \& Daud, 2016). However, it is undeniable that the source of foreign workers helps the development of the country in building office buildings, factories on industrial sites, mega national projects such as construction of public infrastructure, railways and serving in services involving the public or users such as security guards, and cleaning workers (Hamzah \& Daud, 2016). In this context, private companies are strongly encouraged to invest in the cultivation of fruits and vegetables on a large scale so that the food import bill which currently reaches RM60 billion can be reduced. 


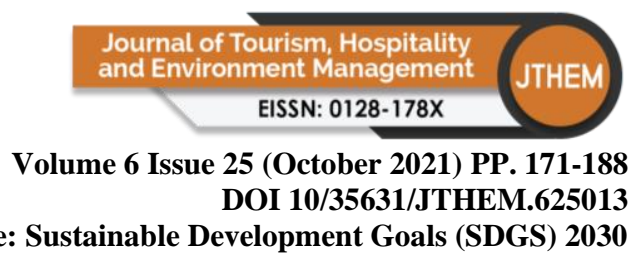

Special Issue: Sustainable Development Goals (SDGS) 2030 According to the former Prime Minister of Malaysia, Tun Dr. Mahathir Mohamad, only large companies that mostly operate palm oil and rubber on a large scale at present and there is no doubt that this is indeed vulnerable to volatile market prices that can cause great losses to the economy (Aziz, Alfitri, Sepeai, Nawi, \& Er, 2021). Whereas, the potential for the cultivation of vegetables and fruits is huge in economic growth and in turn increase the progress of the country's agricultural sector. This is further enhanced when the agricultural and resource economist, Prof. Datuk Dr. Mad Nasir Shamsudin stated that investment in the vegetable sector will provide the fastest return to reduce the food import bill which has reached RM60 billion (Berita Harian, 2019b).

The government's move in encouraging the private sector to invest in the cultivation of vegetables and fruits also provides a relevant solution to the problem that plagues most countries, which is the food security. Food security is very crucial, and the country should have stock up adequate supply of food security for unforeseen circumstances such as crisis. Investment in food sector is not only seen at personal gain, but also social gain where the return is national security in terms of food security itself (Aziz, Alfitri, Sepeai, Nawi, \& Er, 2021). In this regard, the agricultural sector plays a role because the cultivation of vegetables and fruits requires a more planned, integrated and comprehensive venture to increase the results of these efforts.

\section{Research and Development Efforts in the Agriculture Sector}

Research and development in the agricultural sector is very important as a factor in developing the country's agricultural sector. Research and development in the agricultural sector are specifically conducted by the Malaysian Agricultural Research and Development Institute (MARDI) (MARDI, 2021). MARDI's role has evolved from capacity building, establishment of cultivation and plantation systems towards technology commercialisation, total quality management and culture of excellence to achieve national and international recognition (MARDI, 2021). Among the functions and objectives of this institute is to conduct research in terms of science, technical, economic and social with regard to the production, use and processing of all crops (except rubber, palm oil and cocoa), livestock and food as well as mixed plantations.

MARDI also serves as a centre that provides specialist services in the food and agricultural and agro-based industries such as consulting services, analytical laboratories, quality assurance and contract $\mathrm{R} \& \mathrm{D}$, provides various types of training to develop the food and agricultural and agrobased industries, provides assistance to R\&D in the fields of pure science, applied science, technical and economics with regard to the agricultural industry, conducting research and commercial production, developing, promoting and exploiting research findings, as well as providing extension services to the food and agriculture industry and agro-based industries (MARDI, 2021). Among the efforts made by MARDI recently is to create the opening of a Green Agriculture Centre of Excellence in Cameron Highland with the hope of further strengthening the research and development (R\&D) conducted by this agency (Utusan, 2021b).

The centre is the sole research established to further strengthen MARDI's research and development (R\&D) by focusing primarily on disease research and post-harvest handling of vegetables, fruits and flowers, soil conservation research and collection, conservation and use of upland crop genetic resources (Utusan, 2021b). At the same time, MARDI also launched two MARDI technologies namely Multi Virus Biopesticide Technology and Organo Plus Copyright (C) GLOBAL ACADEMIC EXCELLENCE (M) SDN BHD - All rights reserved 


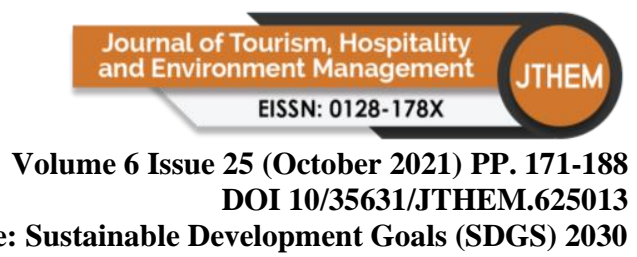

Special Issue: Sustainable Development Goals (SDGS) 2030

Fertiliser, which benefit environmentally friendly upland crops and at the same time, crop productivity can also be increased (Utusan, 2021b). Multi Virus Biopesticide technology is effective in controlling the attack of four Lepidoptera pests in cabbage fields in addition to being environmentally friendly (Utusan, 2021b).

The result of this modern technology also allows beneficial insects such as bees and wasps to not continue to be killed and do not leave residue. Vegetable crops can also be harvested directly and reduce the development of pest resistance or immunity to chemical pesticides. Organo Plus fertiliser has been tested for its effectiveness on vegetables and flowers where it can supply macro and trace nutrients (Utusan, 2021b). With this, crop yields can be increased, and crop soil can also be fertilised with continuous application. In other words, this technology has improved soil quality fertility with prolonged use and is suitable for all soil types and crops. This of course saves the cost of expenditure required in producing the productivity of crop production in large quantities. Apart from MARDI, Higher Education Institutions (HEI) also play a key role in contributing advanced technology and innovation and subsequently transfer to all sectors of the national economy (MOE, 2010).

This is so because the development of the country and the productivity of the economic sector at present depends on the generation of ideas, intellectual capital and new knowledge that is thoughtful and innovative. In this regard, HEIs should be ready and always produce high calibre researchers and actively involved in research, development and commercialisation (R\&D\&C) and also implement research activities that have commercial viability (MOE, 2010). High priority is given so that the agricultural research activities of HEIs are relevant and the results of the research must also ensure commercialisation and be able to penetrate the market not only at the domestic level, but also to penetrate the international market. Thus, the results of agricultural research and development can upgrade the economy and can be used as a catalyst for the third engine of development (third engine of growth) (MOE, 2010).

\section{Improvement of Agricultural and Food Industry E-Commerce}

The increase in online agricultural trade occurred due to many small traders and hawkers choosing this method as a business strategy when movement control order was implemented to generate their income (Berita Harian, 2020e). Online commerce is conducted under the Electronic Commerce Act 2006 and the Consumer Protection Act 1999 (Adnan, Manap, Zakaria, Samuri, Zain, Ahmad, Ong \& Abdullah, 2020). Small traders and hawkers face difficulty conducting business as usual because the rules implemented during the movement control order direct them to close the business premises. As a result, this affects their income generated through business activities.

During the implementation of the movement control order, all small business activities were not allowed to operate and only supermarkets that sell people's necessities such as food supplies and daily necessities as well as clinics and pharmacy are allowed to operate (Department of Information Malaysia, 2020). Meanwhile, small and medium enterprises (SMEs) such as hawkers and small traders like fruit and vegetable stall operators had to stop trading during the movement control order to curb the spread of Covid-19. This affects the entrepreneurs of small and medium enterprises because they cannot sell their goods and not able to generate income. However, this situation provides encouragement and stimulus to SME entrepreneurs to venture into the field of online business (E-commerce) to conduct transactions and sell agricultural products digitally through social media (Fabeil, Pazim \& Langgat, 2020). Copyright (C) GLOBAL ACADEMIC EXCELLENCE (M) SDN BHD - All rights reserved 


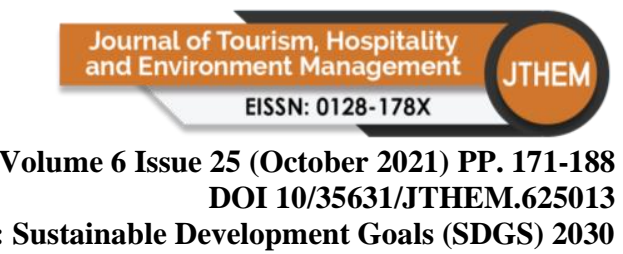

Online business is one of the strategies that can help them carry out agricultural activities without violating the rules set when the movement control order is implemented, and it is easier to do with low risk of pandemic transmission. For example, small traders such as fruit and vegetable hawkers, or food supply traders of livestock resource traders such as eggs and raw chickens can conduct business through social media like Facebook, Instagram and Whatsapp. They conduct product marketing online and then deliver and distribute customer orders using the services of a private courier, freight forwarder or deliver the product personally. In short, small traders who were affected by the movement control order implemented in curbing the Covid-19 pandemic opted for online trading methods to do business which results to a positive impact on the field of agricultural e-commerce.

\section{Industry Revolution and Internet of Things Concept}

In an effort to advance and attract the attention of Malaysians to their involvement in the country's agriculture and food industry, there are various types of initiatives and assistance available and provided to make this a success. Among the things that can be utilised to attract the attention of the people in starting a career in agriculture and food industry is to conduct research and use the technological advances of the Industrial Revolution 4.0 and apply the use of this technology in carrying out their work (Kilmanun \& Astuti, 2020). For example, the use of this technology has already been encouraged by the government in an effort to move towards smart agriculture especially among the youth of generation $\mathrm{Y}$ and $\mathrm{Z}$ because they are smarter through mastering the technology (Berita Harian, 2019c).

The Industrial Revolution has introduced the concept of Internet of Things (IoT), where in this concept it refers to the collection and transfer of data over a network connected in a common internet network (Meutia, 2015). Objects that are found to have the same identification identity and IP address are able to carry out the communication process through the transfer and reception of data, facilitating information to be disseminated and known by the owner of the network (Meutia, 2015). The use of IoT in agriculture can be diversified and it can also reduce the workload faced by farmers and thus increase productivity and crop quality as it has given advantages in terms of time management for farmers to ensure the quality of their crops is taken care of (Meutia, 2015). This is because the country's agricultural sector contributes around 8.2 percent to the Gross National Income (GNI) and has provided 28 percent employment opportunities to the country's population in 2017, thus showing that this sector is still relevant in bringing profit to the country financially (Berita Harian, 2019c).

Meanwhile in 2019, through traditional farming methods that are still practiced by farmers in Malaysia, it has contributed around 8 percent to Gross Domestic Product, showing that if these farmers are given exposure to the benefits offered by the Industrial Revolution 4.0 technology, it is indirectly able to increase their production output and income (Berita Harian, 2021b). The application of IoT technology is already being utilised in the country to help reduce the workload of farmers and it can be seen through the vineyard project at MARDI Agrotechnology Park located on Langkawi Island where they use a network from telecommunications company Maxis to help monitor the crops (Berita Harian, 2021b). The application of technology where it is used to record variables that are among the important factors in ensuring fertility and growth of grapes such as soil moisture, ambient light, $\mathrm{pH}$ value, temperature and ambient air humidity (Berita Harian, 2021b). 


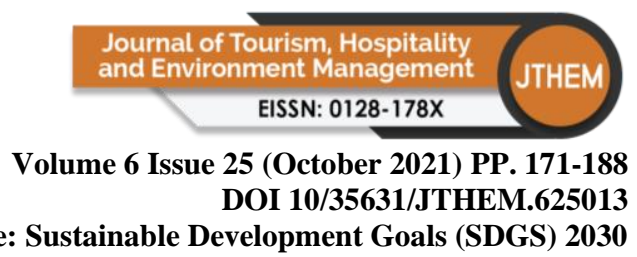

Special Issue: Sustainable Development Goals (SDGS) 2030

This technology can help in providing information to farmers if there are any changes in terms of the environment of their vines and is able to ensure maximum crops production in line with the optimal use of the technology (Berita Harian, 2021b). It will indirectly be able to help in the results achieved as well as save costs and improve their efficiency in terms of crops management as well as reduce losses that will be incurred and create new business opportunities for the country's industry. Apart from IoT, Industrial Revolution 4.0 has also introduced the adaptation of technology, so that it is not only used for a task but maximise the use of the technology that it can simplify our daily lives. For example, the use of drones and Artificial Intelligence (AI) which was previously used in science as one of their research tools, is now widely applied in agriculture (Berita Harian, 2021b).

The use of drones in agriculture in Malaysia is still new, but with effective exposure it can attract modern farmers to switch to this technology to maximise the production of their crops. The use of drones equipped with sensors allows the drones to take pictures of their crops and the analysis process can be done only based on the pictures without the need for farmers to go down to the field thus saving time and initiatives for problem solving can be taken to increase productivity (Bernama, 2020). The sensor serves to determine the rate of soil moisture, detect diseases on trees and also any presence of pests that can affect the production of the crops (Bernama, 2020). Through a drone operation course under the Agriculture Pilot Drone programme offered by Woegard AG (M) Sdn Bhd was held through a collaborative process with Arau Community College students (Bernama, 2020).

Among the purpose of using drones is to facilitate the process of spraying pesticides which is one of the priorities in agriculture to prevent pests from affecting the growth of their crops, and for each planting season, the process of spraying pesticides is usually carried out six times (Bernama, 2020). The advantage of using drones is that it can save time taken for the process of spraying pesticides, where using traditional methods takes one hour to cover an area of one hectare and the use of drones can save 40 minutes for the same area (Bernama, 2020). Apart from that, it can also save costs if compared to the payment of labour wages of RM120 for an area of one hectare, while the cost of using a drone is only RM60 for the same area (Bernama, 2020). Thus, it clearly shows that with the use and application of Industrial Revolution 4.0 technology in agriculture it can attract the people of this country especially the youth because they have been exposed to this technology while in learning, so it makes it easier for them to understand and adapt the following technologies to agricultural direction.

Apart from the use of Industrial Revolution 4.0 technology to encourage people's participation in agriculture, among other initiatives taken is to introduce the concept of online trade to enable the marketing of agricultural products to be marketed more widely (Kilmanun \& Astuti, 2020). Coupled with the spread of the Covid-19 pandemic, this method of marketing is very suitable for the current situation where the movement of the people is limited because of the effort to curb the spread of this pandemic in Malaysia. By running an online business, it can make it easier for consumers to buy without having to leave their homes. Suitable for the working group as well, who do not have time to go to the farmers' market and those who do not have farmers' market facilities in their residential areas.

In an effort to materialise this, the Johor branch of the Federal Agricultural Marketing Authority (FAMA) has strengthened online trade to help farmers affected by the spread of this pandemic (Hmetro, 2020b). By providing a solution to the problems faced by farmers who are Copyright (C) GLOBAL ACADEMIC EXCELLENCE (M) SDN BHD - All rights reserved 


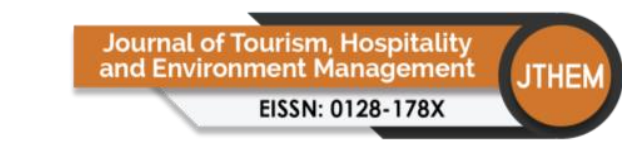

Volume 6 Issue 25 (October 2021) PP. 171-188

DOI 10/35631/JTHEM.625013

Special Issue: Sustainable Development Goals (SDGS) 2030

worried about their products not being sold due to the Movement Control Order (MCO) restrictions that were enforced last year, this online trade has been able to help sell 100 tonnes of crops such as pineapple, water chestnut, cucumbers, red chillies, and leafy vegetables in the state with a sales value of RM200,500 (Hmetro, 2020b). These agricultural products are marketed at the Controlled Farmers Market in the state and it is also marketed abroad to meet demand in the market and also the online trade can be done through the link, www.agrobazaaronline.com.my (Hmetro, 2020b).

This can ensure that the general public's demand for agricultural products can be met and it also helps farmers so that they do not suffer losses due to the current situation. For example, vegetable growers operating in Cameron Highlands are reported to produce 800 metric tonnes of vegetables per day but only 30 percent of that amount is sold due to the MCO being implemented and they are estimated to incur losses of RM1 million per day (Mohd Nawi, 2020). This is because with traditional business method these farmers usually operate through the help of middlemen who will buy their agricultural products and then sell to retailers. Due to the current situation, it becomes difficult for them and that is why alternative ways have been provided to ensure they can meet the food supply to meet the market demand and avoid losses (Mohd Nawi, 2020).

Apart from the aforementioned Agrobazaar portals, farmers can also opt for other online business services such as GrabMart and Lazada which also provide sales services of agricultural products as well as food products based on other raw materials (Mohd Nawi, 2020). This initiative will not only ensure the survival of the agricultural sector in the country during the pandemic period, but it will also provide new knowledge to farmers to operate not only through traditional methods but also in line with the mission to uphold modern agriculture and further enhance their productivity. Online commerce is also able to create a more flexible lifestyle, in line with the needs of youths who value the division of time between their work and personal time and it can also encourage those who venture into this style of marketing to be more creative and innovative in order to run an online business.

\section{Concluding Thoughts}

The Covid-19 outbreak affected the income and employment of the agricultural community. Most of the agricultural community consists of smallholders as well as rural communities such as villagers who carry out agricultural activities privately namely rice cultivation, vegetables and fruits and are sold to earn a living. The implementation of the movement control order restricts the agricultural activities of these communities to harvest agricultural products and makes it difficult for them to sell these products in the market. In addition, marketing in rural areas is also less than in urban areas. This has caused them selling agricultural products at retail. Retail sales provide less income compared to supplying agricultural produce to the market or traders and this makes it difficult for them to generate income compared to selling agricultural produce to the market or to wholesalers.

Even with a pandemic situation that does not allow small-scale sales or hawkers to open stalls, it is more difficult for rural farmers to earn income from the sale of their agricultural resources. In addition, there are a number of agricultural workers who do not work full-time or do not have a formal contract to work in the agricultural sector. This increases their risk of being fired or asked to take unpaid leave. In fact, some of the agricultural sector workers are foreigners. These workers typically work as lorry drivers, farm workers and factory workers processing Copyright (C) GLOBAL ACADEMIC EXCELLENCE (M) SDN BHD - All rights reserved 


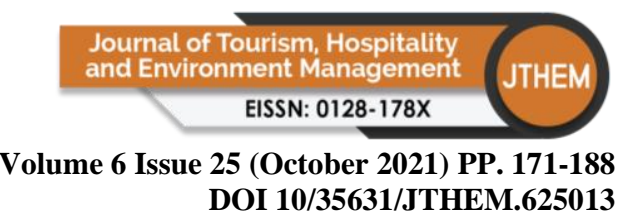

Special Issue: Sustainable Development Goals (SDGS) 2030

agricultural produce. These groups also face the risk of being retrenched if employers need to reduce the number of employees due to social distancing or minimising business costs.

Some agricultural communities also consist of small and medium enterprises (SMEs). Agricultural SME entrepreneurs rely entirely on the trade of agricultural products to generate their income. The implementation of a movement control order that orders all small businesses not to operate for long period of time can cause SME entrepreneurs to suffer severe losses and can even cause them to go bankrupt. In relation to this description, it is clear that the spread of the Covid-19 pandemic has a negative impact on the income and employment of the agricultural community if it persists over a long period of time. The spread of Covid-19 pandemic which affects not only our country but also other countries as well as giving a clear impact on the agricultural industry and food supply in our country.

Based on the description given, Covid-19 has a negative impact such as causing problems in the agricultural sector namely excessive amount of wastage on agricultural products, the decline of the aquaculture sector and affecting the income and employment of the agricultural community. Excessive wastage of agricultural produce occurs when agricultural produce such as vegetables and fruits cannot be sold due to the lack of workers, roadblocks and closure of business premises such as markets, and this has caused the produce to be discarded. The decline in the aquaculture sector was due to the increased costs of livestock care and management when livestock could not be sold and also due to lack of demand from wholesalers and seafood traders who could not trade due to movement control order.

The spread of this pandemic also affects the income and employment of the agricultural community. This is because with the implementation of movement control order the agricultural communities who consist of smallholders and rural communities who generate income by selling agricultural products could not market their agricultural products. At the same time, agricultural sector workers also face the risk of losing their jobs due to the country's economy declining caused by the pandemic which occurs in the country. However, Covid-19 also has a positive impact which is the increase in online agricultural trade (E-commerce). Small and medium entrepreneurs choose this method to carry out business activities after not being allowed to open their business premises due to the implementation of movement control order. Therefore, we must think positively, innovatively and creatively to address the impact of Covid-19 in the agriculture and food supply sectors. People must be wise and give their cooperation to the government in preventing and controlling the spread of Covid-19 so that sectors in the national economy such as the agricultural industry can be fully restored as well as increase national income and promote national development.

\section{Acknowledgement}

This article is part of the UMS and UPSI (TLS2113) collaborative publishing grant sponsorship funded by Global Academic Excellence (GAE). The authors would like to express their deepest heartfelt appreciation to Global Academic Excellence (GAE) for providing funding this publication. 


\section{References}

$\begin{gathered}\text { Journal of Tourism, Hospitality } \\ \text { and Environment Management } \\ \text { EISSN: 0128-178X }\end{gathered}$
Volume 6 Issue 25 (October 2021) PP. 171-188
DOI 10/35631/JTHEM.625013

Abazue, C.M., Er, A.C., A.S.A., Ferdous Alam \& Halima, B. (2015). Oil Palm Smallholders and Its Sustainability Practices in Malaysia. Mediterranean Journal of Social Sciences, 6 (6 S4): 482-488.

Abdul Aziz, A., Mohd Sukor, N., \& Ab Razak, N. (2020). Wabak Covid-19: Pengurusan Aspek Kesihatan Mental Semasa Norma Baharu. International Journal of Social Science Research, 2(4), 156-174.

Adnan, A. M., Manap, N. A., Zakaria, Z., Samuri, M. A. A., Zain, M. N. M., Ahmad, A. A., Ong, T. C., \& Abdullah, F. (2020). Definisi ‘Penipuan' dalam Pembelian dalam Talian: Analisis Terhadap Peruntukan Undang-Undang Di Malaysia. International Journal of Law, Government and Communication, 5 (21): 111-129.

Aris, N. M., P.Rameli, M. F., Mohamed, N., Abas, S. A., \& Man, N. C. (2018). Prestasi Tanaman Padi Di Malaysia. Journal of Islamic, Social, Economics and Development. 3 (11), 51-61.

Astroawani. (2020a). Apa Kesan Covid-19 Kepada Industri Akuakultur di Malaysia? Retrieved From: https://www.astroawani.com/berita-malaysia/apa-kesan-covid19- kepadaindustri-akuakultur-dimalaysia-235864.

Astroawani. (2020b). Kerajaan Sasar Penghasilan Beras Tempatan Kepada 75 Peratus - Ronald Kiandee. Retrieved From: https://www.astroawani.com/berita-malaysia/kerajaansasar-penghasilan-beras-tempatan-kepada-75-peratus-ronald-kiandee-268609.

Aziz, A. N. A., Alfitri, N. A., Sepeai, N., Nawi, N. F. M., \& Er. A. C. (2021). Kelestarian Penanaman Kelapa Sawit Terhadap Pensijilan Mspo dalam Kalangan Pekebun Kecil Sawit di Lahad Datu, Sabah. Journal of Tourism, Hospitality and Environment Management, 6 (22), 65-78.

Begum, H., Siwar, C., Ferdous, A. A. S. A., Er, A.C., Suraiya, I. \& Lubna, A. (2018). Enhancing Sustainability Amongst Oil Palm Smallholders in Malaysia. International Journal of Agricultural Resources, Governance and Ecology, 14(1): 62-79.

Berita Harian. (2021a). Sektor Sawit Paling Terkesan Kekurangan Pekerja - Khazanah Research. Retrieved From: https://www.bharian.com.my/Bisnes/LainLain/2021/01/779692/Sektor-Sawit-Paling-Terkesan-Kekurangan-Pekerja-KhazanahResearch.

Berita Harian. (2021b). Pertanian Pintar Guna Teknologi Iot: Retrieved From: https://www.bharian.com.my/Bisnes/Teknologi/2021/02/789182/Pertanian-PintarGuna-Teknologi-Iot.

Berita Harian. (2020a). Covid-19: Perutusan Khas Perdana Menteri Mengenai Perintah Kawalan Pergerakan. Retrieved From: https://www.bharian.com.my/berita/nasional/2020/03/665970/covid-19-perutusankhas-perdana-menteri-mengenai-perintah-kawalan.

Berita Harian. (2020b). Sawit Punca Rezeki Bantu Pembangunan Negara. Retrieved From: https://www.bharian.com.my/kolumnis/2020/07/710975/sawit-punca-rezeki-bantupembangunannegara

Berita Harian. (2020d). Belanjawan 2021: Semua Rakyat Dapat Manfaat. Retrieved From: https://www.bharian.com.my/berita/nasional/2020/11/751262/belanjawan-2021semua-rakyat-dapat-manfaat.

Berita Harian. (2020e). Covid-19 Lonjak Penggunaan E-Dagang. Retrieved From: https://www.bharian.com.my/bisnes/teknologi/2020/05/689812/covid-19-lonjakpenggunaan-e-dagang 


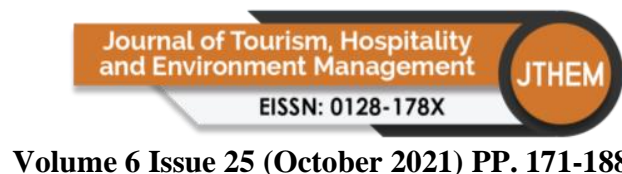

DOI 10/35631/JTHEM.625013

Special Issue: Sustainable Development Goals (SDGS) 2030

Bernama. (2020). Tinta Minda. Didapatkan Dari Tingkatkan Hasil Pertanian Melalui Teknologi Pertanian Tepat: Retrieved From: https://www.bernama.com/bm/tintaminda/news.php?id=1878066.

Berita Harian. (2019a). Malaysia Hasil 188 Bilion Sarung Tangan Getah. Retrieved From:

https://www.bharian.com.my/bisnes/lain-lain/2019/04/552163/malaysia-hasil-188-bilionsarung-tangan-getah.

Berita Harian. (2019b). Ladang Sayur, Buah akan Kurangkan Import Negara dalam 2 Tahun. Retrieved

From: https://www.bharian.com.my/berita/nasional/2019/10/622123/ladang-sayur-buahakankurangkan-import-negara-dalam-2-tahun.

Berita Harian. (2019c). Didapatkan Dari Generasi Digital, Milenium 'Kunci' Pertanian Pintar.

Retrieved From: https://www.bharian.com.my/rencana/muka10/2019/08/600119/generasidigital-milenium-kuncipertanian-pintar.

Che Omar, S., Shaharudin, A., \& Tumin, S. A. (2019). The Status of Paddy and Rice Industry in Malaysia. Kuala Lumpur: Khazanah Research Institute.

Chew, W. K., \& Chamhuri, N. (2018). Sektor Padi dan Beras Malaysia Berbanding Indonesia: Mengkaji Trend dan Dasar Pertanian di Kedua-Dua Negara. International Journal of Business, Economics and Law, 17 (3): 70-76.

Fabeil, N. F., Pazim, K. H., \& Langgat, L. (2020). Impak Krisis Covid-19 Terhadap Sektor Pertanian: Strategi Saluran Pengagihan bagi Kesinambungan Perniagaan. Jurnal Dunia Perniagaan, 2 (1): 1-8.

Hamzah, I. S., \& Daud, S. (2016). Implikasi Kemasukan Pekerja Asing di Malaysia: Suatu Tinjauan Awal. Sains Insani, 01: 69-77.

Hmetro. (2020a). Isu Lambakan Sayur akan Diselesaikan [Metrotv]. Retrieved From: Https: https://www.hmetro.com.my/mutakhir/2020/04/565247/isu-lambakan-sayur-akandiselesaikan-metrotv.

Hmetro. (2020b). Fama Perkasa Jualan atas Talian: Retrieved From: https://www.hmetro.com.my/mutakhir/2020/04/563123/fama-perkasa-jualan-atastalian.

Hmetro. (2018). Potensi Jadi Pengeksport Beras. Retrieved From: Https: https://www.hmetro.com.my/agro/2018/09/377134/potensi-jadi-pengeksport-beras.

Jabatan Pertahanan Negara. (2020). Sektor Agrikomoditi. Retrieved From:https://docs.jpa.gov.my/docs/pelbagai/2020/sop/10_sop_\%20sektor_\%20agriko moditi\%20_mpic.pdf.

Jabatan Penerangan Malaysia. (2020). Kenyataan Media: Majlis Keselamatan Negara. Retrieved From: https://www.penerangan.gov.my/japenv2/index.php/2020/03/18/kenyataanmediamajlis-keselamatan-negara-jabatan-perdana-menteri-18-mac-2020/.

Kementerian Perusahaan Perladangan dan Komoditi. (2018). Anggaran Perbelanjaan Persekutuan 2018. Kementerian Perusahaan Perladangan dan Komoditi. Retrieved from: https://www.mof.gov.my/arkib/expenditure/2018/b.20.pdf.

Kementerian Pertanian Malaysia. (1993). Dasar Pertanian Negara (1992-2010). Kuala Lumpur: Unit Penerbitan Kementerian Pertanian Malaysia.

Kilmanun, J. C., \& Astuti, D. W. (2020). Potensi dan Kendala Revolusi Industri 4.0 di Sektor Pertanian. Prosiding Seminar Nasional Kesiapan Sumber Daya Pertanian dan Inovasi Spesifik Lokasi Memasuki Era Industri 4.0: 35-40 


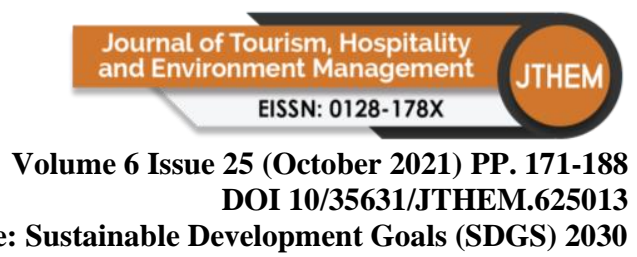

Special Issue: Sustainable Development Goals (SDGS) 2030

Koris, R., Nik Mustapha, N. H., Abd. Aziz, A., \& Muhamad, S. (2012). Transformasi Industri

Akuakultur Pantai Timur Ke Arah Kecekapan Teknikal. Prosiding Perkem Vii, Jilid 1: 260268

Mardi. (2021). Latar Belakang Mardi. Retrieved From: https://blogmardi.wordpress.com/about/.

Meutia, E. D. (2015). Internet of Things-Keamanan dan Privasi. Seminar Nasional dan Expo Teknik Elektro: 85-89.

MOE. (2010). Hala Tuju Bidang Pertanian. Retrieved From:

https://www.moe.gov.my/muat-turun/penerbitan-dan-jurnal/rujukan-Akademik/1427-HalaTuju-Bidang-Pertanian/File.

Mohd Nawi, N. (2020). Bertukar kepada Pemasaran Online Produk Tani. Retrieved From:https://agri.upm.edu.my/artikel/bertukar_kepada_pemasaran_online_produk_tan i-56514.

Sinar Harian. (2021). Malaysia dalam Senarai 10 Pengeluar Utama Getah Asli Dunia. Sinar Harian. Retrieved From: https://www.sinarharian.com.my/article/133989/berita/nasional/malaysia-

Dalamsenarai-10-Pengeluar-Utama-Getah-Asli-Dunia

Sinar Harian. (2020). [Laporan Khas] Pekebun Sayur Cameron Highlands Rugi Rm1 Juta Sehari. Retrieved From: https://www.sinarharian.com.my/article/76148/laporankhas/[laporan-khas]pekebun-sayur-cameron-highlands-rugi-rm1-juta-sehari.

Sinar Harian. (2019). Penoreh Padang Terap Resah Harga Getah Tak Menentu. Retrieved From:https://www.sinarharian.com.my/article/45068/edisi/utara/penoreh-padangterap-resah-harga-getah-tak-menentu.

Tahir, S. H., \& Abd Talip, M. (2020). Dasar Keselamatan Makanan di Sabah, Malaysia: Kajian Kes Jelapang Padi Di Daerah Kota Belud. Jurnal Kinabalu Bil. 26 (1): 23-39.

Unit Perancang Ekonomi. (2010). Rancangan Malaysia Kesepuluh (2011-2015). Retrieved From: http://www.pmo.gov.my/dokumenattached/rmk/rmk10_mds.pdf.

Unit Perancang Ekonomi. (1996). Rancangan Malaysia Ketujuh (1996-2000). Kuala Lumpur: Jabatan Percetakan Negara.

Utusan. (2021a). Petani Perak 'Pening', Dakwa Sayur Tak Terjual. Retrieved From: https://www.utusan.com.my/terkini/2021/06/petani-perak-pening-dakwa-sayur-takterjual/.

Utusan (2021b). Mardi Tubuh Pusat Penyelidikan Pertanian Hijau Tanah Tinggi. Retrieved From:https://www.utusan.com.my/berita/2021/04/mardi-tubuh-pusat-penyelidikanpertanianhijau-tanah-tinggi/.

Zakaria, M. B., Mohd Nor, A. H., Mohamed Said, M. L., Ahmad, M., Y., \& Hassan, J. (2017). Dasar Pertanian Negara Ketiga (DPN3) \& Dasar Agromakanan Negara (Dan): Analisis Terhadap Makanan Asasi Beras dan Padi Menurut Islam. Jurnal Islam Dan Masyarakat Kontemporari, 14: 32-49. 